\title{
USE OF PRECURSORS FOR THE PRODUCTION OF CAST METALLIC FOAMS
}

\author{
UPORABA PREKURZORJEV ZA IZDELAVO LITIH KOVINSKIH \\ PEN
}

\author{
Ivana Kroupová ${ }^{1 *}$, Petr Lichý1 ${ }^{1}$, Václav Merta ${ }^{1}$, Ivo Lána ${ }^{2}$ \\ ${ }^{1}$ VSB - Technical University of Ostrava, Faculty of Materials Science and Technology, Department of Metallurgy and Foundry Engineering, \\ 17. listopadu 2172/15, 70800 Ostrava - Poruba, Czech Republic \\ ${ }^{2}$ SaM Nové Ransko, s.r.o., Nové Ransko 234, 58263 Ždírec nad Doubravou, Czech Republic \\ Prejem rokopisa - received: 2018-07-11; sprejem za objavo - accepted for publication: 2018-10-30
}

doi:10.17222/mit.2018.141

\begin{abstract}
The presented work was devoted to the development of the production processes for metallic foams, which were based on conventional casting technologies. The use of the standard casting processes and standard materials made it possible to identify the range of metallic foams amongst affordable materials, thereby making a full use of their application potentials. The experimental part was focused on the development and subsequent optimization of the casting processes for manufacturing cast metallic foams with irregular inner-cell structures, and especially on the development of the technology of infiltrating molten metal into a mold cavity filled with precursors.

Keywords: metallic foam, precursor, casting, irregular structure
\end{abstract}

Avtorji predstavljajo razvoj procesa izdelave kovinskih pen, ki temelji na konvencionalnih tehnologijah litja. Zaradi uporabe standardne livarske prakse in materialov spadajo kovinske pene med dostopne materiale, in tako je mogoč poln izkoristek njihovega potenciala. Eksperimentalni del študije je bil osredotočen na razvoj in takojšnjo optimizacijo livarskega postopka izdelave kovinskih pen z nepravilno notranjo celično strukturo. Delo je bilo še posebej osredotočeno na razvoj tehnologije infiltracije kovinske taline $\mathrm{v}$ votlino orodja, ki je bila pred tem napolnjena s predhodno surovino (prekurzorjem).

Ključne besede: kovinske pene, prekurzor, litje, nepravilne strukture

\section{INTRODUCTION}

Porous metals represent a new type of material with new physical and mechanical properties. These are characterized by, e.g., low density, high specific surface area, acoustic or thermal insulation properties, etc. They are very suitable for specific applications due to a good combination of physical and mechanical properties such as high specific strength and high energy-absorption capability. ${ }^{1}$ As a result, metallic foams can be used in many fields of human activities. However, the application potential of these materials is limited by the economic demands of their production technologies. In most cases, these are costly methods based on complicated procedures and the use of non-standard and expensive input materials. ${ }^{2-4}$ For this reason, the application of casting processes for the production of such materials is a suitable solution.

Mastering inexpensive ways of manufacturing metallic foams, not requiring production facilities with investment-intensive machines and equipment is a prerequisite for a full utilization of the application potentials of these materials. That is why the experimental part of the presented work was devoted to the casting technol- ogies for the production of metallic foams based on conventional foundry processes.

For successful casting, it is necessary to know the technological and metallurgical parameters of the production. It is assumed that a thorough knowledge of the production parameters and conditions will contribute to the expansion of the foundry assortment, which can also increase its competitiveness on a global scale.

\section{EXPERIMENTAL PART}

There are several foundry methods for the production of porous metals, such as investment casting technology (using an evaporative pattern), which is considerably expensive. ${ }^{5}$ The experimental part of this paper deals with an optimization of the procedure for the production of cast metallic foams, using the infiltration method, which ensures a rapid and economically feasible production of shaped components.

For all experiments, the castings were made of the Al-Si type alloy (AlSi10MgMn) and the molds were made from a commonly used molding mixture (green sand).

*Corresponding author e-mail:

ivana.kroupova@vsb.cz 


\subsection{Infiltration of molten metal into a mold filled with precursors}

The principle of this technology (Figure 1) is to pour liquid metal into a mold filled with particles (precursors). The irregular structure of the pores we deal with can be achieved with the use of various types of precursors that fill the mold cavity. The precursors must be made of a material that preserves its shape during the impact of the molten metal (sufficient strength, low abrasion, refractoriness) and they must also allow good disintegration after the casting. ${ }^{6}$ In the experiment, we made castings with irregular cell structures, using particles based on conventional molding mixtures.

The possibility to control the cellular structure (pore size, porosity, etc.) is a very important advantage of the use of a foundry technique to manufacture metallic foams.

\subsection{Precursors - the Croning process}

The core particles were manufactured from the molding mixture (from the rejected cores produced during the Croning process). The final globular shape of the core precursors was achieved by splitting them into small pieces $(10-30 \mathrm{~mm})$, followed by tumbling. The mold cavity was filled with these precursors.

\subsection{Precursors - a furan molding mixture}

To create these precursors a plastic grill was used as the core box. Using this core box, cubes with a side length of $25 \mathrm{~mm}$ were created. This was followed by tumbling. The proposed technology provides for a production of precursors of the same size, shape and properties.

\subsection{Precursors - a PUR cold box}

These precursors were made from rejected special cores (preforms, used for manufacturing metallic foams with a regular inner-cell structure), from the materials commonly used in foundries. This core production technology is based on a two-component binder system (benzyletherpolyol and diphenylmethane-4-4-diisocyanate) and is a suitable process for producing geometrically and formally complex cores. Through this procedure, we obtained precursors of the same size and shape.

\subsection{Salt precursors}

The last tested type of the filler material included precursors from a salt-based core composition. From the prepared molding mixture, beams were made, which were cured and subsequently cut into cubes. These semi-finished products were then placed on a rotating screen where they were tumbled. This precursor-manufacturing process is similar to that described in section
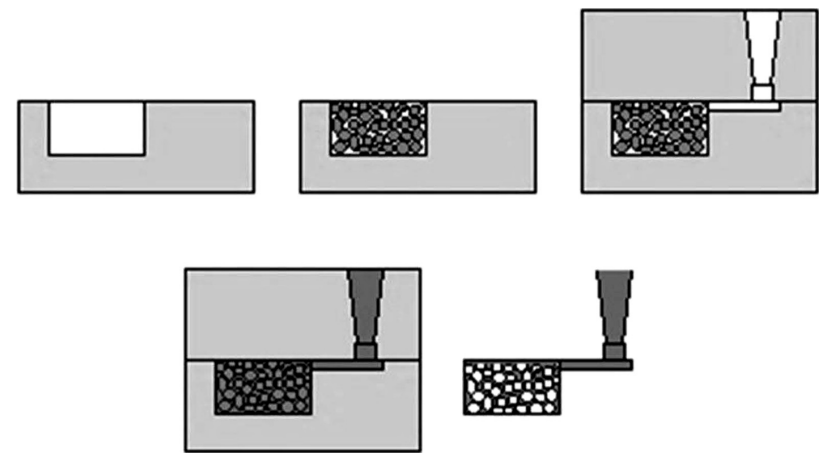

Figure 1: Principle of infiltrating molten metal into a mold filled with precursors

2.3. The average size of the resulting precursors made with the above procedure was $20 \mathrm{~mm}$.

\section{RESULTS}

Four types of materials and technologies for manufacturing precursors were investigated. The porosity of all produced castings amounted to $60 \%$. The main advantage of Croning precursors is the possibility of using waste materials. The disadvantage of these precursors is their irregular shape, caused by uneven tumbling of the cullet due to the non-uniform hardening of the default core mixture. Therefore, a new technology for precursor manufacturing was proposed - the use of a molding mixture bonded with a furan resin. This type of precursor manufacturing should ensure the achievement of the same size, shape and defined characteristics of the precursors. In addition, precursors allow good disintegration after the casting. The production of precursors from preforms (special types of cores) provides for the possibility of producing particles of the same size and shape from a waste material. The use of the salt precursors appears to be very appropriate with respect to their removal from the casting volume. After the casting, it is possible to remove them immediately after the solidification of the casting with spillage from all internal cavities (assuming the precursors touch each other to form interconnected cavities). The process of mechanical removal of the filler material, which was a common disadvantage of all the above-mentioned processes, can thus be eliminated.

\section{DISCUSSION}

The use of common molding mixtures for the manufacture of precursors was approved. With regard to the possibility of utilizing waste materials, the use of rejected cores is optimal. With respect to the possibility of removing precursors from the complex structure of a casting, the use of salt precursors or precursors from a furan molding mixture is particularly advantageous. 


\section{CONCLUSIONS}

It was verified that metallic foams can be produced through a common casting process using the existing technologies and current materials. With these methods, foams with irregular internal structures can be prepared from modified materials that are normally processed in foundries.

Thanks to the technology of infiltration of molten metal into a mold filled with precursors, it is possible to produce shaped castings with open pores that are interconnected. The condition for achieving this type of porosity is complete filling of the mold cavity with precursors. With this technology, we are able to change the shape, size and location of individual precursors, and thus the resultant pores in the casting.

This process of manufacturing metallic foams fully meets the original requirements - it is a low-cost technology based on commonly used foundry operations. In addition, when using waste materials, we can partly address the issue of waste disposal, which is a concern of every industrial field.

\section{Acknowledgment}

The contribution was made with the support of the Technology Agency of the Czech Republic TH02020668 and the support of projects of "Student Grant Competition" numbers SP2019/148 and SP2019/43.

\section{REFERENCES}

${ }^{1}$ J. Banhart, Manufacture, characterisation and application of cellular metals and metal foams, Progress in Materials Science, 46 (2001) 6, 559-632, doi:10.1016/S0079-6425(00)00002-5

${ }^{2}$ L. J. Gibson, Biomechanics of cellular solids, Journal of Biomechanics, 38 (2005), 377-399, doi:10.1016/j.jbiomech.2004.09.027

${ }^{3}$ F. García-Moreno, Commercial Applications of Metal Foams: Their Properties and Production, Materials, 85 (2016) 9, doi:10.3390/ ma9020085

${ }^{4}$ L. Drenchev, J. Sobczak, S. Malinov, W. Sha, Gasars: a class of metallic materials with ordered porosity, Materials Science and Technology, 22 (2006) 10, 1135-1147, doi:10.1179/174328406X118302

${ }^{5}$ I. Kroupová, P. Lichý, F. Radkovský, J. Beňo, V. Bednářová, I. Lána, Optimization of the annealing of plaster moulds for the manufacture of metallic foams with an irregular cell structure, Mater. Tehnol., 49 (2015) 4, 527-530, doi:10.17222/mit.2014.132

${ }^{6}$ P. Lichý, T. Elbel, I. Kroupová, F. Radkovský, Preparation and evaluation of properties of cast metallic foams with regular inner structure, Archives of Metallurgy and Materials, 62 (2017) 3, 1643-1646, doi:10.1515/amm-2017-0251 